\title{
Paraoxonase 1 (PON1) Activity, Polymorphisms and Coronary Artery Disease
}

\author{
Nidhi Gupta, Kiran Dip Gill and Surjit Singh \\ Post Graduate Institute of Medical Education and Research, Chandigarh, \\ India
}

\section{Introduction}

Cardiovascular disorders (CVD) which include coronary artery disease (CAD), heart failure (HF) and stroke are the leading cause of morbidity and mortality both in developed and developing countries and by $2020 \mathrm{CAD}$ is expected to become the number one cause of death worldwide ${ }^{1-3}$. As per WHO, CVD kills nearly 17.5 million persons worldwide each year and is likely to continue to remain number one cause of overall mortality in near future ${ }^{4,5}$.

CAD is the single most important contributor to this increasing burden of CVD. It leads to more deaths than any other disease, including cancer. It can manifest as angina, silent ischemia, unstable angina, myocardial infarction (MI), HF and sudden death. CAD accounts for $52 \%$ of 870,000 deaths that occur annually due to CVD in USA i.e. 1 in 5 deaths ${ }^{6}$ and nearly accounts for $30 \%$ of all deaths globally. Among American Indians in age group (4574) the incidence of CVD ranges from $1.5 \%-2.8 \%$ for men and $0.9-1.5 \%$ for women 7 .

Ethnic and regional variations are known to exist in risk factors for developing CVD. The Asian Indians are 3- 4 times more susceptible to develop CAD than Caucasians, 6- times more than Chinese, and 20- times more than Japanese and tend to develop CAD at a younger age 8,9 as shown by several studies ${ }^{10-13}$. The study SHARE (Study of Health Assessment and Risk in Ethnic groups) has shown a significant higher risk of cardiovascular events among South Asians as compared to Europeans and Chinese 13.

\section{Pathophysiology of CAD}

The most important underlying pathogenetic mechanism for CVD is atherosclerosis 14,15 . $\mathrm{CAD}$ occurs due to atheromatous narrowing and subsequent occlusion of the coronary arteries. Atheroma [from the Greek athera (porridge) and oma (lump)] starts developing in the first decade of life. A mature plaque has a lipid core which comes from necrotic "foam cells" i.e. monocyte derived macrophages which migrate to intima and ingest lipids (fig. I) ${ }^{16}$.

Epidemiological studies have shown an inverse correlation between serum HDL-C levels and risk for developing CAD 17, 18. The protective effect of HDL-C against the development of CAD appears to be complex. A large part of research in this field is centered on the lipid 
transport function of HDL-C, particularly in reverse cholesterol transport (RCT). In addition, several studies suggest that HDL-C protects LDL-C from peroxidation, thereby protecting cell membranes from lipid peroxide induced vascular damage. This protection of LDL-C from oxidation by HDL-C possibly potentially impedes the initiation and progression of CAD. Recent studies into the mechanism of the prevention of CAD by HDL-C have revealed that its antioxidant effect is because of its association with an enzyme "paraoxonase".

\section{Paraoxonase (PON1; EC 3.1.8.1)}

In 1946, Abraham Mazur was the first to report the presence of an enzyme in animal tissues which could hydrolyze organophosphates ${ }^{19}$ which ultimately led to the identification of human serum paraoxonase (PON1) enzyme in early 1950's 20. PON1 is a HDL-C associated serum enzyme whose primary role is to protect LDL-C from oxidative modification ${ }^{21}$.

PON1 was first identified in the field of toxicology as it could hydrolyze the organophosphates such as paraoxon, and oxon metabolite of chlorpyriphos, diazinon and nerve gases (e.g., sarin and soman)22. Indeed, the enzyme (EC 3.1.8.1) was initially characterized as organophosphate hydrolaze and it still derives its name from its in vitro used substrate, paraoxon. Recently, in addition to its role in hydrolyzing organophosphorus compounds, PON1 has been shown to play an important role in lipid metabolism and thus in atherosclerosis and cardiovascular disease.

The PON1 cDNA encodes a protein of 355 amino acids from which only the amino-terminal methionine residue is removed during secretion and maturation ${ }^{23}$. The retained leader sequence is required for the association of PON1 with HDL particle ${ }^{24}$. In human serum, PON1 remains entirely associated with HDL ${ }^{25}$.

PON1 lowers the risk of CAD by preventing oxidation of LDL-C which is involved in the initiation and progression of atherosclerosis 26 (Fig. I). Studies have shown that PON1 can prevent accumulation of oxidized LDL-C in vitro and in vivo ${ }^{27-29}$. In addition, it has also been shown to hydrolyze the oxidized lipids ${ }^{30}$. Serum PON1 activity is reduced in diabetes mellitus and familial hypercholesterolemia ${ }^{31,32}$, diseases which are associated with accelerated atherogenesis.

\subsection{PON1 structure}

The first information about the structure of PON1 was the finding that it retained its signal sequence following secretion from the liver ${ }^{23}$. Sorenson et al., 24 demonstrated that this signal sequence provided a hydrophobic anchor for attachment of PON1 to HDL. Josse et al., 33, 34 identified the following amino acid residues which are essential for PON1's catalytic activity: W280, H114, H154, H242, D53, D168, D182, D268, D278, E52, E194 and the two cysteine residues C41 and C352 that are in disulfide linkage.

A major breakthrough in PON1 structural study came with the engineering of a directed evolution $^{35}$ of a form of PON1 that could be crystallized and subjected to X-ray crystallography ${ }^{36}$ resulting in determination of crystal structure of the recombinant PON variant, making PON1 the first HDL-associated protein whose three-dimensional structure could be determined ${ }^{36}$. PON has a six-bladed $\beta$ - propeller with each blade consisting of four 
$\beta$-sheets. In the central tunnel of the enzyme there are two calcium atoms which are needed for the stabilization of the structure and catalytic activity 36 . Three a helices, located at the top of the propeller are involved in its anchoring to the HDL particle 36

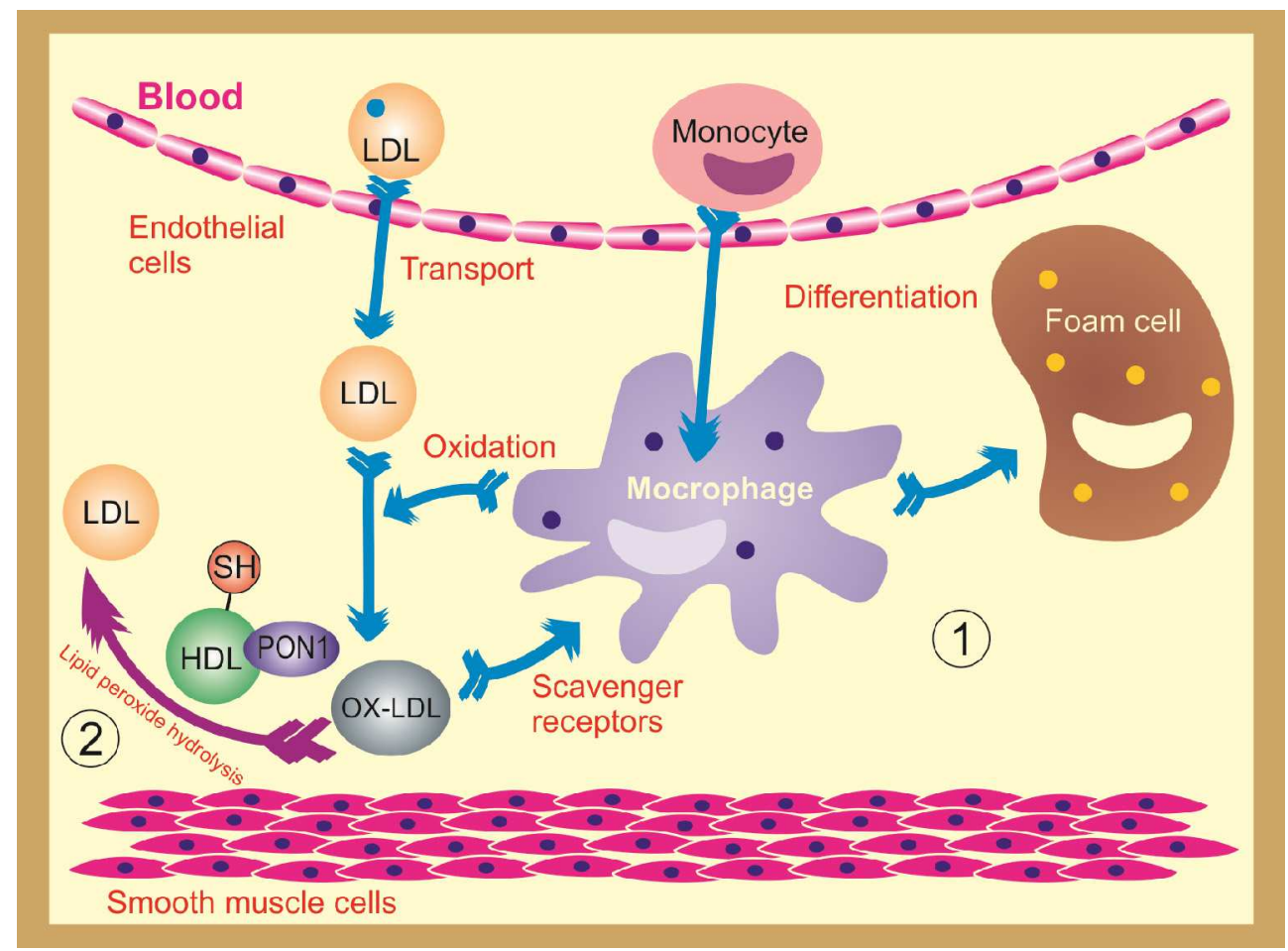

Fig. 1. (1). Normal development of atherosclerosis. (2). Protection from atherosclerosis by PON1.

PON1 contains three Cys residues with one at position 284, having a free sulfhydryl group (Fig. I). PON1 is the only one whose allozymes are found in serum. A unique feature of PON1 in comparison to the other secreted proteins is the retention of its N-terminal hydrophobic signal-leader sequence. Immunological techniques have revealed that PON1 accumulates in the human arterial wall during the development of atherosclerosis ${ }^{37}$.

\subsection{PON gene cluster}

In addition to the known human PON1 gene, two additional PON-like genes, designated as PON2 and PON3 have been identified and all these three genes are located on the long arm of chromosome 7q 21.3-22.1 38. These genes share a considerable structural homology and may have arisen from the tandem duplication of a common evolutionary precursor. Within a given mammalian species PON1, PON2 and PON3 share approximately $60 \%$ identity at the amino acid level and $70 \%$ identity at the nucleotide level. However, between mammalian species each of three genes shares $79-90 \%$ identity at the amino acid level and $81-90 \%$ identity at nucleotide levels 26 . 


\subsection{Paraoxonase 2 (PON2)}

PON2 is a widely expressed intracellular protein with a molecular mass of approximately $44 \mathrm{kDa}{ }^{39}$. PON2 mRNA is ubiquitously expressed in nearly every human tissue with highest expression in liver, lung, placenta, testis, and heart. PON2 is able to lower the intracellular oxidative stress of a cell and prevent the cell-mediated oxidation of LDL. Cells over expressing PON2 are less able to oxidize LDL-C and show considerably less intracellular oxidative stress when exposed to either $\mathrm{H}_{2} \mathrm{O}_{2}$ or oxidized phospholipids. Since PON2 is ubiquitously expressed not just in cells of the artery but in tissues throughout the body, it is likely that PON2 plays a role in reducing local oxidative stress ${ }^{39}$ and thereby protects cells from oxidative stress. However, the mechanism by which this effect is produced is not clearly understood.

\subsection{Paraoxonase 3 (PON3)}

Human PON3 is an approximately $40 \mathrm{kDa}$ protein, synthesized primarily in the liver and is associated with HDL in circulation, albeit at much lower level than PON1 ${ }^{40}, 41$. PON3 is interposed between PON1 and PON2 in the PON gene cluster and is the least studied compared to PON1 and PON2. In contrast to PON1, PON3 has very limited arylesterse and no paraoxonase activity but it rapidly hydrolyzes lactones such as statin prodrug.

All the three PON's are thus important players in the maintenance of a low oxidative state in circulating blood, therefore playing role in prevention of atherosclerosis 42 . However, as exact mechanism of action is not clear, they remain the focus of research in recent years.

\section{PONs substrates}

PON's native enzyme activity is lactonase 43,44 . Phylogenetic studies have revealed that PON2 is the oldest member of family from which PON3 and PON1 arose 45. Draganov et al.,, 46 found that PON's have distinct substrate specificity. Dihydrocoumarin (DHC), long chain fatty acid lactones and acyl- homoserine lactones (AHLs) are hydrolyzed by all the three PONs and represent their natural substrates 44. Additionally, PON1 also hydrolyzes organophosphates and aromatic carboxylic acid esters such as paraoxon and phenylacetate respectively 47 thereby having paraoxonase (PONase) and arylesterase (AREase) activities ${ }^{48}$.

\subsection{Paraoxonase (PONase) activity}

There exists a wide variation in PONase activity in different ethnic groups and within individuals in the same ethnic group ${ }^{49}$. The PONase activity has been shown to be lower after acute myocardial infarction 50. It is also lower in patients with familial hypercholesterolemia and diabetes mellitus, who are more prone to CAD 31 . This has led to the hypothesis that the lower the PON1 activity, higher is the accumulation of oxidized LDL and risk of CAD.

Nearly 200 single nucleotide polymorphisms (SNPs) of PON1 gene have been identified so far, 51 of which the most studied are -909G/C [rs854572], -162A/G [rs705381], -108C/T [rs 705379] located in the promoter region and Q192R [rs662], L55M [rs 854560] located in the coding region ${ }^{52}$. Serum PONase activity has been found to be influenced by the coding Q192R polymorphism ${ }^{53}$. The PON1 R192 allozyme hydrolyzes paraoxon more rapidly than 
PON1 Q192 allozyme whereas PON1 Q192 allozyme hydrolyzes diazoxon, soman and sarin more rapidly than the R192 allozyme 54, 55 .

\subsection{Arylesterase (AREase) activity}

Serum enzyme PON1 activity is not affected towards phenylacetate (AREase) substrate across Q192R polymorphism ${ }^{56}$. Richter et al., 51 have stated that measurement of AREase activity of PON1 or determination of PON1 protein levels by ELISA are the minimum measure that should be carried out in any epidemiological study. Thus it can act as measure of PON levels and this has been used in a number of studies. $48,51,56-58$.

\subsection{Lactonase activity}

Lactonase activity is possibly the common enzymatic activity preserved during evolution of the PON proteins. Recent findings suggest that the name PON is infact a misnomer, since PON2 and PON3 lack any significant paraoxonase activity 39-41. At the molecular level PON1, PON2 and PON3 share an ability to hydrolyze aromatic and long-chain aliphatic lactones, and thus the term lactonase may be more appropriate 44,45 .

Further, the binding of PON1 to HDL particles i.e. the natural carrier of PON1 in blood, has been shown to greatly enhance its lactonase activity. However arylesterase or phosphotriesterase activities are not affected by this. PON1 and PON3 hydrolyze over twenty aromatic and aliphatic lactones with a high degree of overlapping substrate specificity, whereas PON2 lactonase activity is much more restricted.

\section{PON1 activity/ levels and CAD}

There have been several epidemiological studies to find the relation between PON1 status and CAD. PON1 status can be distinguished into PON1 activity towards paraoxon and PON1 concentration, which is mainly determined in serum by ELISA or can be estimated from phenylacetate hydrolysis activity. The first study on the relation between PON1 activity and CAD was conducted in 1985 50. The outcome of this study indicated that lower the PON1 activity, higher was risk of CAD. Subsequently Navab et al., ${ }^{59}$ showed that patients with higher HDL-C but low PON1 activity were more susceptible to CAD than patients with low HDL-C but high PON1activity, suggesting that PON1 activity may be more important than HDL protein for protection against CAD. In subsequent, three studies, investigating the relationship of PON1 status and CAD found that low PON1 activity or levels were associated with an increased risk of CAD ${ }^{60-62}$ suggesting that PON1 activity predicted coronary events independent of HDL-C.

There is a wide variation (up to 13 -fold) in PON1 serum concentration and activity between individuals even within the same genotype 55,61 . In addition to genetic polymorphism, PON1 levels can be modified by acquired factors such as diet, lifestyle and disease. It is likely to be the functionality of the enzyme and not simply the genotype that is important in the interaction of PON1 with CAD. A small number of recent studies which include PON1 concentration and/or activity, have found that PON1 levels are reduced in CAD and found this effect is independent of PON1 genotype 61,63 . In a case-control study of CAD, Jarvik et $a l ., 61$ could not find any genotype effect unless PON1 activity was also considered. 
A functional genomic analysis as measurement of an individual's PON1 function (serum activity) takes into account all the polymorphisms which might affect its activity. This can be accomplished by use of a high-throughput enzyme assay involving two PON1 substrates usually diazoxon and paraoxon ${ }^{55}$. This, in addition to providing a functional assessment of the serum PON1 192, alloforms also provide the levels of PON1 for each individual, thus encompassing the two factors which affect PON1 levels or activity (position 192 amino acid and serum alloform level). This approach has been referred to as the determination of PON1 'status' of an individual 55. Measurement of PON1 status, coupled with PCR analysis of codon 192, has been shown to detect genotypes / activity discrepancies that can be explained by the presence of recently discovered mutations in the PON1 gene 63 .

Fundamental biochemical principal dictates that it is the catalytic efficiency with which PON1 degrades toxic organophosphates and metabolizes oxidized lipids that determines the degree of protection provided by PON1 against insults from physiological or xenobiotic toxins. In addition, the higher concentration of PON1 provides better protection. Thus, for adequate risk assessment it is important to know PON1 level and activity.

The importance of PON1 status in determining susceptibility or protection from toxicity or disease points to the relevance of factors affecting PON1 activity and its levels of expression. Though genetic determinants such as polymorphisms play a primary role in determining an individual's PON1 status, contribution of other factors in modulating PON1 activity and levels is also important 21,64 .

\section{PON1 gene polymorphisms and CAD}

\subsection{PON1 coding region polymorphisms and CAD}

There is 10-40 -fold interindividual variation in serum PON1 activity 53, 65 and this variation in part is determined by 2 common polymorphisms in the coding region of the PON1 gene. The first polymorphism involves glutamine ("A genotype") $(\mathrm{Q}) \rightarrow$ arginine ("B genotype") (R) substitution at position 192, giving rise to 2 allozymes 53, 66. These allozymes have different activity for different substrates. Some substrates such as paraoxon and fenitroxon are hydrolyzed faster by $\mathrm{R}$ allozyme, whereas other substrates such as phenylacetate are hydrolyzed at the same rate by both allozymes ${ }^{22}$. However, others such as diazoxon and nerve gases soman and sarin are hydrolyzed more rapidly by the Q allozyme ${ }^{22}$. The Q192R polymorphism may be playing a role in CAD etiology because this genotype is associated with LDL oxidation and hydrolysis of lipid peroxides. The PON1 192R isoform is less effective at hydrolyzing lipid peroxides than $Q$ isoform 67,68 . A second polymorphism of the PON1 gene is present at the amino acid position 55, a leucine ("L genotype") $(\mathrm{L}) \rightarrow$ methionine ("M genotype") (M) substitution, independently influences PON1 activity and has been defined as the molecular basis for this interindividual variability 53,66 . It is independent of the 192 polymorphism and appears to be the major determinant of the well known biochemical polymorphism in serum PON1 activity towards various organophosphates.

The frequency of PON1 alleles varies greatly across the human population. The distribution of two polymorphisms is significantly different between white and black women. The frequency of the PON1 M55 allele is higher in whites than in blacks, whereas the frequency of the PON1 R192 allele is reverse ${ }^{69}$. The lowest frequency of the PON1 M55 allele has been 
reported in Chinese. The relatively high frequency of the PON R192 allele in blacks is similar to that reported in Chinese and Japanese varying from 58\% to 65\% 70,71 . However, Ferre et al., 72 found no significant differences in genotype and allele frequencies for PON1 polymorphisms at position 55 and 192 between control subjects and patients with myocardial infarction in a Spanish population. The frequencies were similar to those described for other Caucasian populations. These two polymorphisms have significant linkage disequilibrium. Several case-control studies conducted in Caucasians and in Japanese have shown that the Q192R is associated with increased risk of CAD 73-77, although others have failed to replicate this association $71,78-82$. Other studies have indicated that Q192R polymorphism is associated with altered PON1 enzyme activity for paraoxon as a substrate 53,66. On the other hand, Garin et al., 83 reported that in a French population L55M polymorphism may be a major genetic determinant of PON1 enzyme activity and of increased risk for CAD whereas discordant results were obtained in Singapore in Asian Indians and Chinese 84 and in Japanese 73. In North- West Indian Punjabi's, Q192R was independently associated with CAD (QR (OR: 2.73 (1.57-4.72)) and RR (OR, 16.24 (6.4141.14) ${ }^{58}$. These results suggest that PON1 R might be an independent risk factor for CAD only in certain populations. Thus, the association between the PON1 polymorphism and CAD is not clear and continues to remain controversial.

The dramatic alteration in enzyme activity caused by this single amino acid change is explained by the structure of the enzyme. Amino acid $192 \mathrm{R}$ is an important active site residue ${ }^{36}$. The Q192R polymorphism alters the enzyme's ability to protect LDL-C from oxidation in vivo with the $Q$ form being the most protective 67 .

The PON1 L55M polymorphism does not affect the interaction of PON1 with its substrates, but is associated with lower serum PON1 activity and concentration of the enzyme ${ }^{83}$. Leviev et al., 85 found lower PON1 mRNA levels in individuals carrying the $\mathrm{M}$ alleles. Subsequent analysis showed a strong linkage disequilibrium with the C (-108)T polymorphisms in the promoter region of the gene. Clinical reports have demonstrated that PON1 activity is reduced in patients with acute myocardial infarction 60 , fish eye disease 86 and tangier disease ${ }^{87}$. Lower paraoxonase activity has been observed in Type 2 diabetes mellitus patients with peripheral neuropathy ${ }^{32}$ and retinopathy ${ }^{88-90}$.

Watson et al., ${ }^{29}$ have shown that purified PON1 can prevent the pro-inflammatory effects of oxidized LDL when incubated in a vascular cell co-culture system, probably due to the mechanism of oxidized-arachidonic acid derivatives in the Sn-2position of LDLphospholipids. Of the PON1 192 allozymes the R allozyme proved to be more efficient at protecting LDL-C from oxidation. Numerous case-control studies have therefore been conducted to determine whether the PON1 192R polymrphism is more closely associated with CAD than the Q polymorphism. Some studies have shown association whereas others have not ${ }^{21}$. However, a recent meta-analysis has revealed a statistically significant increased likelihood of CAD with the PON1 192R allele. Some studies suggest that the PON1 R allele may increase susceptibility to other established CAD risk factors, such as diabetes mellitus 88, cigarette-smoking ${ }^{91}$ and age ${ }^{92}$. The PON1 55L allozyme is also more effective in vivo in protecting LDL-C against oxidation than M allozyme. Few case-control studies of the 55 polymorphism have been done. Some have shown an association between the PON1 55L allele and atherosclerosis 83,93 , but others have not 84,94 . However, no prospective studies of $\mathrm{CAD}$ and PON1 polymorphisms are available. Moreover the association between CAD and 
PON1 genotype although largely confirmatory is not the only test for hypothesis that PON1 protects against CAD. This may be due to acquired factors acting either on the composition of the lipid environment of HDL, in which PON1 operates, or on the promoter region of the PON1 gene or in some manner as yet to be identified. When PON1 activity is measured directly in patients with CAD, it is about half that of the disease-free controls 50,60 . Ayub et al., 60 have observed low PON1 activity within few hours of the onset of myocardial infarction, suggesting a low serum PON1 activity to precede the event. Low serum PON1 activity independent of genotype has been reported in several other disorders, which are known to be associated with CAD. These include experimental and clinical diabetes mellitus $31,32,88,95,96$, hypercholesterolemia ${ }^{31}$ and renal failure ${ }^{97}$.

Interestingly, in addition to preventing LDL-C oxidation, PON1 may also stimulate cellular cholesterol efflux, the first step in reverse cholesterol transport. Thus, PON1 might affect the efficiency of lipid transfer between HDL-C and LDL-C 26. Also, Rodrigo et al., 98 demonstrated that PON1 may play a role in protecting against bacterial endotoxins and may have a stabilizing property for cellular membranes that undergo either acute or chronic exposure to oxidative agents and free radicals.

\subsection{PON1 promoter region polymorphisms and CAD}

Sequencing of the promoter PON1 gene led to the discovery of at least five polymorphisms with varying degree of influence over gene expression. These polymorphisms are located at $-909(\mathrm{G} / \mathrm{C}),-832$ (A/G), -162 (A/G), -126(C/G) and -108 (C/T) 99-101 of PON1 gene. Promoter containing polymorphisms GAAC, as opposed to CGGT, at positions -909,-832, -162 and 108 respectively, are up to two times more active $99-101$. These variations in promoter activity have been shown to be physiologically relevant as they correlate with significant differences in serum PON1 concentration and activity 99-101.

Identification of clinically significant polymorphisms has been hampered by the fact that there is significant linkage disequilibrium between all the promoter polymorphisms. Haplotype analysis of two populations showed that the $\mathrm{C}(-108) \mathrm{T}$ polymorphism was the main contributor to the serum PON1 variation, accounting for $23-24 \%$ of the total variation 100 . Brophy et al., 100 also reported a slight contribution (1.1\% total variation) from the A (-162) G site. The sites at -909 and -832 made little or no difference to serum PON1 levels 100, 102 .

Reporter gene assays using promoter regions of varying length have shown that approximately 200 base pair region covering the -108 and -162 polymorphism is sufficient for transcription of the PON1 gene 102-104. Deleting this region completely abolishes promoter activity, indicating that it is an essential regulatory region of the promoter 102 site of PON1 gene.

As the -108 site appears to be the most significant contributor to the PON1 serum variation, it has been the subject of further investigation. The polymorphism is located in the center of a consensus binding site for the ubiquitous transcription factor sp1 and $\mathrm{sp} 3$. This consensus site is abolished by the presence of the $-108 \mathrm{~T}$ variant 99,100 .

Binding of the sp1 to the -108 site is weaker in the presence of $T$ than $C$, suggesting an effect of the polymorphism on sp1 binding ${ }^{102}$. There are multiple Sp1 sites in this region of the 
PON1 promoter, so the effect of the polymorphism is likely to be positional. The -162 polymorphism lies over a potential NF-1 (nuclear factor-1) binding site, with the high activity A variant forming the site and the low-activity $G$ variant disrupting it ${ }^{103}$. This may explain the effect of the change at -162 on gene expression. Other polymorphisms in the promoter region $(-162 \mathrm{~A} / \mathrm{G}$, and $-909 \mathrm{G} / \mathrm{C})$ may have less significant effect on PON1 expression. They are in strong disequilibrium with C-108T 105.

The increasing role attributed to PON1 in assuring protective mechanisms associated with HDL-C underlines the need to clarify fully the factors which control gene expression and thus modulate the serum PON1 concentration.

\subsection{PON1 haplotypes and CAD}

Determination of haplotypes is gaining attention because multiple linked SNP's have the potential to provide significantly more power to genetic analysis than individual SNP's ${ }^{106}$. Information is lacking regarding PON1 haplotypes and CAD risk. In North-West Indian Punjabi's L-T-G-Q-C (carrying 4 variant and 1 wild type allele) and L-T-G-R-G (carrying 4 variant and 1 wild type allele) haplotypes are associated with 3.2 and 2.8 fold increase in the risk of CAD whereas haplotypes M-C-A-Q-G (carrying all wild type allele), L-T-A-Q-G (carrying 2 variant and 3 wild type allele) and L-C-A-Q-G (carrying 1 variant and 4 wild type allele) which are more prevalent in controls could be protective of CAD ${ }^{58}$.

\section{PON1 polymorphisms and lipoproteins}

Many studies have suggested that variation in serum PON1 activity is associated with variation in serum lipoprotein concentration including the serum apoA1, LDL-C and HDLC. Several studies have been conducted to determine the relationship between PON1 gene polymorphisms and serum lipoproteins in Hutterite North American population genetically isolated by religious belief. Further analysis of this population using several candidate genes led 107 to reveal that PON1 was one of nine genes which was responsible for between 3.2 and $7.8 \%$ of the total variation in plasma lipoproteins in them. The PON1 genotypes were significantly associated with variation in the plasma concentration of HDL-C, LDL-C, TG and apo B ${ }^{107}$. Homozygotes for the low activity variant of PON1 had significantly lower levels of plasma triglycerides, LDL and apo-B than heterozygotes and homozygotes for the high activity variant. Furthermore, homozygotes for the low-activity variant had significantly lower ratios of total cholesterol/HDL-C, LDL -C/HDL- C and apo B/apo A1 indicating that homozygotes for the low activity allele had a less atherogenic lipoprotein profile than heterozygotes and homozygotes for the high activity allele.

More recently, Leus et al., 108 found that a significant difference in mean TC and LDL-C levels between subjects with the PON1 LL55 and MM55 genotype, and PON1 MM55 had a better plasma lipoprotein profile.

Watson et al., 29 (the Fogelman group) have reported that PON1 in HDL may block inflammatory response by preventing the oxidation of LDL. The same group has also shown that during an acute-phase response, there was a significant loss of the PON1 activity, thus accounting for the failure of HDL to protect LDL from oxidation during it 109. More recently the same group ${ }^{59}$ have reported a failure of HDL to protect LDL from oxidation in patients with CAD, which they propose is due to low serum PON1 activity in them. 


\section{Modulation of PON1 by exogenous compounds}

\subsection{Environmental chemicals}

PON1 activity is completely dependent upon $\mathrm{Ca}++$ and EDTA, irreversibly abolishes its activity. Other cations, also, have been shown to have an inhibitory effect on PON1 activity. The barium, lithium, copper, zinc and mercurials have been found to inhibit PON1 activity in rat and human liver ${ }^{110}$. In case of mercurials and copper, studies suggest that a free thiol group on the Cys 285 residue may be the molecular target 110, 111. More recent experiments have revealed that cadmium, iron, zinc and mercurials are highly potent in vitro inhibitors of PON1 192R activity and can inhibit upto $80 \%$ of activity. However, in vivo the PON Q192 appears to be less sensitive to inhibition by metals, with the exception of lead ${ }^{112}$. In vivo exposures of mice to cadmium, methylmercury or dietary iron leading to metal serum concentration of higher than $1 \mu \mathrm{M}$ has failed to alter PON1 activity in plasma and liver 112 . This is probably due to binding of metal to proteins in plasma leading to protection of PON1.

\subsection{Classical inducers}

A few studies have investigated whether PON1 is an inducible enzyme. Phenobarbital, a classical enzyme inducer which is particularly effective toward certain isozymes of cytochrome P450 (e.g. CYP2B), caused a modest (20-150\%) increase in hepatic PON1 activity 113, with a concomitant increase in liver RNA levels 114 . However, serum PON1 activity has been found to be decreased in patients on (40-50\%) phenobarbital treatment ${ }^{113-116 .}$

\section{Modulation of PON1 by life-style factors}

Enzyme inducers, environmental chemicals, physiological and pathological states, and dietary and lifestyle factors have shown their effects on PON1 activity.

\subsection{Age}

In humans, PON1 serum arylesterase activity increases from birth to 15-25 months of age, when it seems to reach a plateau whose level is determined by the $5^{\prime}$ regulatory-region polymorphisms and the genetic background of the individual 114. In an adult, PON1 levels remain stable as no significant changes have been observed with age 117, 118 .

\subsection{Enzme inducers and environmental chemicals}

3-Methylcholantherene has been found to increase both serum and liver PON1 level in rats 98 but not in mice ${ }^{114}$. Administration of lipopolysaccharide, which mimics gram-negative infection, causes a transient decrease in serum and liver PON1 activity and in hepatic mRNA levels 114, 119. The phytoalexin resveratrol is considered to be a major biologically active component contributing to the beneficial effect of wine ${ }^{120}$ and is known to modulate gene expression.

PON1 activity can vary depending on physiological conditions or pathological states. Serum PON1 activity is significantly decreased during pregnancy 121. 


\subsection{Smoking}

Cigarette smoke extract is known to inhibit PON1 activity in vitro ${ }^{122}$, suggesting that smoking may be detrimental to enzyme activity in vivo. James et al., ${ }^{91}$ showed that PON1 serum concentration and activity were reduced in smokers compared with non-smokers. Exsmokers had activities and concentrations comparable with those of non-smokers, suggesting a reversible influence of smoking on PON1. In vitro experiments found that inhibition of PON1 activity by a cigarette-smoke extract was antagonized by reduced glutathione (GSH), N-acetylcysteine, and 2-mercaptoethanol, suggesting that free thiols are central to the inhibitory effects ${ }^{122}$.

\subsection{Alcohol}

Moderate wine consumption appears to have potential beneficial effects related to the prevention of CAD ${ }^{123}$. Wine consumption increases serum PON1 activity ${ }^{124,125}$. Ethanol and other aliphatic alcohols have been shown to inhibit serum PON1 activity 126; however, in middle aged men daily moderate alcohol consumption increased serum PON1 activity, with no differences between wine, beer, and spirits 127 . This increase may be due to the consumption of alcohol itself or to that of antioxidants, as similar results were obtained after consumption of red wine 128 or pomegranate juice 129,130 .

\subsection{Diet}

In both rabbit and transgenic mouse model, a proatherogenic diet caused a significant fall in PON1 activity, which correlated with a reduction in HDL-cholesterol 89, 131-133. Diets with a high trans-unsaturated fat content can reduce PON1 activity ${ }^{134}$. In contrast, oleic acid from olive oil is associated with increased activity 135,136 . Meals rich in used cooking fat which contains a high content of oxidized lipids, is followed by a significant fall in PON1 activity when fed to healthy men 137 .

PON1 is highly susceptible to inactivation by oxidation. In vitro, PON1 activity is protected by the anti-oxidant polyphenols quercetin and glabridin 138, suggesting that dietary antioxidants may play a similar role in vivo. Some studies have shown that consumption of pomegranate juice which is rich in polyphenols and other antioxidants, can raise PON1 activity up to $20 \%$ in both humans and apoE knockout mice ${ }^{130}$.

\section{Conclusions and future prospects}

Human epidemiological studies and experimental work carried out so far provides convincing evidence that $\mathrm{PON}(\mathrm{s})$ play an important role in protection against atherosclerosis. Studies are required to elucidate the role of the PON genetic polymorphisms in this potentially important function of $\mathrm{PON}(\mathrm{s})$ and role in $\mathrm{CAD}$ and other related diseases. Since nutritional and environmental factors explain some of the individual variations in serum PON 1 activity, the enzyme is considered as a promising target for pharmaceutical intervention. Therefore, pharmacological modulation of PON1 activity or PON 1 gene expression could constitute a useful approach for the prevention of CAD. 


\section{Acknowledgement}

Council of Scientific and Industrial Research- University Grants Commission (CSIR-UGC), New- Delhi, India provided research fellowship to Nidhi Gupta.

\section{References}

[1] Murray, C. J. and Lopez, A. D., Alternative projections of mortality and disability by cause 1990-2020: Global Burden of Disease Study, Lancet, 1997, 349: 1498-1504.

[2] Kullo, I. J. and Ding, K., Mechanisms of disease: The genetic basis of coronary heart disease, Nat Clin Pract Cardiovasc Med, 2007, 4: 558-569.

[3] Tunstall-Pedoe, H., Vanuzzo, D., Hobbs, M., Mahonen, M., Cepaitis, Z., Kuulasmaa, K. and Keil, U., Estimation of contribution of changes in coronary care to improving survival, event rates, and coronary heart disease mortality across the WHO MONICA Project populations, Lancet, 2000, 355: 688-700.

[4] Libby, P., Ridker, P. M. and Maseri, A., Inflammation and atherosclerosis, Circulation, 2002, 105: 1135-1143.

[5] Wang, Q., Advances in the genetic basis of coronary artery disease, Curr Atheroscler Rep, 2005, 7: 235-241.

[6] Rosamond, W., Flegal, K., Friday, G., Furie, K., Go, A., Greenlund, K., Haase, N., Ho, M., Howard, V., Kissela, B., Kittner, S., Lloyd-Jones, D., McDermott, M., Meigs, J., Moy, C., Nichol, G., O'Donnell, C. J., Roger, V., Rumsfeld, J., Sorlie, P., Steinberger, J., Thom, T., Wasserthiel-Smoller, S. and Hong, Y., Heart disease and stroke statistics--2007 update: a report from the American Heart Association Statistics Committee and Stroke Statistics Subcommittee, Circulation, 2007, 115: e69-171.

[7] Thomas K. Welty, E. T. L., Jeunliang Yeh, Linda D. Cowan, Oscar Go, Richard R., Fabsitz, NgoC-Anh Le, Arvo J. oopik, David C. Robbins and Barbara V. Howard., Cardiovasculat Disease Risk Factors among American Indians: The Strong Heart Study., Am J Epidemiol, 1995, 142: 269-287.

[8] McKeigue, P. M., Ferrie, J. E., Pierpoint, T. and Marmot, M. G., Association of early-onset coronary heart disease in South Asian men with glucose intolerance and hyperinsulinemia, Circulation, 1993, 87: 152-161.

[9] Janus, E. D., Postiglione, A., Singh, R. B. and Lewis, B., The modernization of Asia. Implications for coronary heart disease. Council on Arteriosclerosis of the International Society and Federation of Cardiology, Circulation, 1996, 94: 26712673.

[10] Enas, E. A., Garg, A., Davidson, M. A., Nair, V. M., Huet, B. A. and Yusuf, S., Coronary heart disease and its risk factors in first-generation immigrant Asian Indians to the United States of America, Indian Heart J, 1996, 48: 343-353.

[11] Hughes, K., Yeo, P. P., Lun, K. C., Sothy, S. P., Thai, A. C., Wang, K. W. and Cheah, J. S., Ischaemic heart disease and its risk factors in Singapore in comparison with other countries, Ann Acad Med Singapore, 1989, 18: 245-249.

[12] Balarajan, R., Ethnic differences in mortality from ischaemic heart disease and cerebrovascular disease in England and Wales, BMJ, 1991, 302: 560-564. 
[13] Anand, S. S., Yusuf, S., Vuksan, V., Devanesen, S., Teo, K. K., Montague, P. A., Kelemen, L., Yi, C., Lonn, E., Gerstein, H., Hegele, R. A. and McQueen, M., Differences in risk factors, atherosclerosis, and cardiovascular disease between ethnic groups in Canada: the Study of Health Assessment and Risk in Ethnic groups (SHARE), Lancet, 2000, 356: 279-284.

[14] Dawber, T. R., Meadors, G. F. and Moore, F. E., Jr., Epidemiological approaches to heart disease: the Framingham Study, Am J Public Health Nations Health, 1951, 41: 279281.

[15] Ross, R., The pathogenesis of atherosclerosis--an update, N Engl J Med, 1986, 314: 488500.

[16] Grech, E. D., ABC of interventional cardiology: percutaneous coronary intervention. I: history and development, BMJ, 2003, 326: 1080-1082.

[17] Tanne, D., Yaari, S. and Goldbourt, U., High-density lipoprotein cholesterol and risk of ischemic stroke mortality. A 21-year follow-up of 8586 men from the Israeli Ischemic Heart Disease Study, Stroke, 1997, 28: 83-87.

[18] Assmann, G., Schulte, H., von Eckardstein, A. and Huang, Y., High-density lipoprotein cholesterol as a predictor of coronary heart disease risk. The PROCAM experience and pathophysiological implications for reverse cholesterol transport, Atherosclerosis, 1996, 124 Suppl: S11-20.

[19] Mazur, A., An enzyme in animal tissue capable of hydrolyzing the phosphorus-fluorine bond of alkyl fluorophosphates., J. Biol. Chem., 1946, 164: 271-289.

[20] Aldridge, W. N., Serum esterases. I. Two types of esterase (A and B) hydrolysing pnitrophenyl acetate, propionate and butyrate, and a method for their determination, Biochem J, 1953, 53: 110-117.

[21] Durrington, P. N., Mackness, B. and Mackness, M. I., Paraoxonase and atherosclerosis, Arterioscler Thromb Vasc Biol, 2001, 21: 473-480.

[22] Davies, H. G., Richter, R. J., Keifer, M., Broomfield, C. A., Sowalla, J. and Furlong, C. E., The effect of the human serum paraoxonase polymorphism is reversed with diazoxon, soman and sarin, Nat Genet, 1996, 14: 334-336.

[23] Hassett, C., Richter, R. J., Humbert, R., Chapline, C., Crabb, J. W., Omiecinski, C. J. and Furlong, C. E., Characterization of cDNA clones encoding rabbit and human serum paraoxonase: the mature protein retains its signal sequence, Biochemistry, 1991, 30: 10141-10149.

[24] Sorenson, R. C., Bisgaier, C. L., Aviram, M., Hsu, C., Billecke, S. and La Du, B. N., Human serum Paraoxonase/Arylesterase's retained hydrophobic N-terminal leader sequence associates with HDLs by binding phospholipids : apolipoprotein A-I stabilizes activity, Arterioscler Thromb Vasc Biol, 1999, 19: 2214-2225.

[25] Blatter, M. C., James, R. W., Messmer, S., Barja, F. and Pometta, D., Identification of a distinct human high-density lipoprotein subspecies defined by a lipoproteinassociated protein, K-45. Identity of K-45 with paraoxonase, Eur J Biochem, 1993, 211: 871-879.

[26] Mackness, B., Durrington, P. N. and Mackness, M. I., The paraoxonase gene family and coronary heart disease, Curr Opin Lipidol, 2002, 13: 357-362.

[27] Mackness, M. I., Arrol, S. and Durrington, P. N., Paraoxonase prevents accumulation of lipoperoxides in low-density lipoprotein, FEBS Lett, 1991, 286: 152-154. 
[28] Mackness, M. I., Arrol, S., Abbott, C. and Durrington, P. N., Protection of low-density lipoprotein against oxidative modification by high-density lipoprotein associated paraoxonase, Atherosclerosis, 1993, 104: 129-135.

[29] Watson, A. D., Berliner, J. A., Hama, S. Y., La Du, B. N., Faull, K. F., Fogelman, A. M. and Navab, M., Protective effect of high density lipoprotein associated paraoxonase. Inhibition of the biological activity of minimally oxidized low density lipoprotein, J Clin Invest, 1995, 96: 2882-2891.

[30] Aviram, M., Rosenblat, M., Bisgaier, C. L., Newton, R. S., Primo-Parmo, S. L. and La Du, B. N., Paraoxonase inhibits high-density lipoprotein oxidation and preserves its functions. A possible peroxidative role for paraoxonase, J Clin Invest, 1998, 101: 1581-1590.

[31] Mackness, M. I., Harty, D., Bhatnagar, D., Winocour, P. H., Arrol, S., Ishola, M. and Durrington, P. N., Serum paraoxonase activity in familial hypercholesterolaemia and insulin-dependent diabetes mellitus, Atherosclerosis, 1991, 86: 193-199.

[32] Abbott, C. A., Mackness, M. I., Kumar, S., Boulton, A. J. and Durrington, P. N., Serum paraoxonase activity, concentration, and phenotype distribution in diabetes mellitus and its relationship to serum lipids and lipoproteins, Arterioscler Thromb Vasc Biol, 1995, 15: 1812-1818.

[33] Josse, D., Xie, W., Renault, F., Rochu, D., Schopfer, L. M., Masson, P. and Lockridge, O., Identification of residues essential for human paraoxonase (PON1) arylesterase/organophosphatase activities, Biochemistry, 1999, 38: 2816-2825.

[34] Josse, D., Lockridge, O., Xie, W., Bartels, C. F., Schopfer, L. M. and Masson, P., The active site of human paraoxonase (PON1), J Appl Toxicol, 2001, 21 Suppl 1: S7-11.

[35] Aharoni, A., Gaidukov, L., Yagur, S., Toker, L., Silman, I. and Tawfik, D. S., Directed evolution of mammalian paraoxonases PON1 and PON3 for bacterial expression and catalytic specialization, Proc Natl Acad Sci U S A, 2004, 101: 482-487.

[36] Harel, M., Aharoni, A., Gaidukov, L., Brumshtein, B., Khersonsky, O., Meged, R., Dvir, H., Ravelli, R. B., McCarthy, A., Toker, L., Silman, I., Sussman, J. L. and Tawfik, D. S., Structure and evolution of the serum paraoxonase family of detoxifying and anti-atherosclerotic enzymes, Nat Struct Mol Biol, 2004, 11: 412-419.

[37] Mackness, B., Hunt, R., Durrington, P. N. and Mackness, M. I., Increased immunolocalization of paraoxonase, clusterin, and apolipoprotein A-I in the human artery wall with the progression of atherosclerosis, Arterioscler Thromb Vasc Biol, 1997, 17: 1233-1238.

[38] Rowles, J., Scherer, S. W., Xi, T., Majer, M., Nickle, D. C., Rommens, J. M., Popov, K. M., Harris, R. A., Riebow, N. L., Xia, J., Tsui, L. C., Bogardus, C. and Prochazka, M., Cloning and characterization of PDK4 on 7q21.3 encoding a fourth pyruvate dehydrogenase kinase isoenzyme in human, J Biol Chem, 1996, 271: 22376-22382.

[39] Ng, C. J., Wadleigh, D. J., Gangopadhyay, A., Hama, S., Grijalva, V. R., Navab, M., Fogelman, A. M. and Reddy, S. T., Paraoxonase-2 is a ubiquitously expressed protein with antioxidant properties and is capable of preventing cell-mediated oxidative modification of low density lipoprotein, J Biol Chem, 2001, 276: 4444444449 . 
[40] Draganov, D. I., Stetson, P. L., Watson, C. E., Billecke, S. S. and La Du, B. N., Rabbit serum paraoxonase 3 (PON3) is a high density lipoprotein-associated lactonase and protects low density lipoprotein against oxidation, J Biol Chem, 2000, 275: 3343533442.

[41] Reddy, S. T., Wadleigh, D. J., Grijalva, V., Ng, C., Hama, S., Gangopadhyay, A., Shih, D. M., Lusis, A. J., Navab, M. and Fogelman, A. M., Human paraoxonase-3 is an HDLassociated enzyme with biological activity similar to paraoxonase- 1 protein but is not regulated by oxidized lipids, Arterioscler Thromb Vasc Biol, 2001, 21: 542-547.

[42] Precourt, L. P., Amre, D., Denis, M. C., Lavoie, J. C., Delvin, E., Seidman, E. and Levy, E., The three-gene paraoxonase family: physiologic roles, actions and regulation, Atherosclerosis, 214: 20-36.

[43] Khersonsky, O. and Tawfik, D. S., Structure-reactivity studies of serum paraoxonase PON1 suggest that its native activity is lactonase, Biochemistry, 2005, 44: 6371-6382.

[44] Draganov, D. I., Teiber, J. F., Speelman, A., Osawa, Y., Sunahara, R. and La Du, B. N., Human paraoxonases (PON1, PON2, and PON3) are lactonases with overlapping and distinct substrate specificities, J Lipid Res, 2005, 46: 1239-1247.

[45] Draganov, D. I. and La Du, B. N., Pharmacogenetics of paraoxonases: a brief review, Naunyn Schmiedebergs Arch Pharmacol, 2004, 369: 78-88.

[46] Draganov, D. I., Lactonases with organophosphatase activity: structural and evolutionary perspectives, Chem Biol Interact, 2010, 187: 370-372.

[47] La Du, B. N., Human Serum paraoxonase/arylesterase. In, Pharmacogenetics of Drug metabolism (W. Kalow.ed.) Pergamon Press, New York USA pp51-91, 1992.

[48] Richter, R. J., Jarvik, G. P. and Furlong, C. E., Determination of paraoxonase 1 status without the use of toxic organophosphate substrates, Circ Cardiovasc Genet, 2008, 1: 147-152.

[49] MacKness, B., Mackness, M. I., Durrington, P. N., Arrol, S., Evans, A. E., McMaster, D., Ferrieres, J., Ruidavets, J. B., Williams, N. R. and Howard, A. N., Paraoxonase activity in two healthy populations with differing rates of coronary heart disease, Eur J Clin Invest, 2000, 30: 4-10.

[50] McElveen, J., Mackness, M. I., Colley, C. M., Peard, T., Warner, S. and Walker, C. H., Distribution of paraoxon hydrolytic activity in the serum of patients after myocardial infarction, Clin Chem, 1986, 32: 671-673.

[51] Richter, R. J., Jarvik, G. P. and Furlong, C. E., Paraoxonase 1 status as a risk factor for disease or exposure, Adv Exp Med Biol, 2010, 660: 29-35.

[52] Costa, L. G., Cole, T. B., Jarvik, G. P. and Furlong, C. E., Functional genomic of the paraoxonase (PON1) polymorphisms: effects on pesticide sensitivity, cardiovascular disease, and drug metabolism, Annu Rev Med, 2003, 54: 371-392.

[53] Humbert, R., Adler, D. A., Disteche, C. M., Hassett, C., Omiecinski, C. J. and Furlong, C. E., The molecular basis of the human serum paraoxonase activity polymorphism, Nat Genet, 1993, 3: 73-76.

[54] Aviram, M., Hardak, E., Vaya, J., Mahmood, S., Milo, S., Hoffman, A., Billicke, S., Draganov, D. and Rosenblat, M., Human serum paraoxonases (PON1) Q and R selectively decrease lipid peroxides in human coronary and carotid atherosclerotic lesions: PON1 esterase and peroxidase-like activities, Circulation, 2000, 101: 25102517. 
[55] Richter, R. J. and Furlong, C. E., Determination of paraoxonase (PON1) status requires more than genotyping, Pharmacogenetics, 1999, 9: 745-753.

[56] Furlong, C. E., Holland, N., Richter, R. J., Bradman, A., Ho, A. and Eskenazi, B., PON1 status of farmworker mothers and children as a predictor of organophosphate sensitivity, Pharmacogenet Genomics, 2006, 16: 183-190.

[57] Berkowitz, G. S., Wetmur, J. G., Birman-Deych, E., Obel, J., Lapinski, R. H., Godbold, J. H., Holzman, I. R. and Wolff, M. S., In utero pesticide exposure, maternal paraoxonase activity, and head circumference, Environ Health Perspect, 2004, 112: 388-391.

[58] Gupta, N., Singh, S., Maturu, V. N., Sharma, Y. P. and Gill, K. D., Paraoxonase 1 (PON1) Polymorphisms, Haplotypes and Activity in Predicting CAD Risk in North-West Indian Punjabis, PLoS ONE, 2011, 6: e17805.

[59] Navab, M., Hama-Levy, S., Van Lenten, B. J., Fonarow, G. C., Cardinez, C. J., Castellani, L. W., Brennan, M. L., Lusis, A. J., Fogelman, A. M. and La Du, B. N., Mildly oxidized LDL induces an increased apolipoprotein J/paraoxonase ratio, J Clin Invest, 1997, 99: 2005-2019.

[60] Ayub, A., Mackness, M. I., Arrol, S., Mackness, B., Patel, J. and Durrington, P. N., Serum paraoxonase after myocardial infarction, Arterioscler Thromb Vasc Biol, 1999, 19: 330-335.

[61] Jarvik, G. P., Rozek, L. S., Brophy, V. H., Hatsukami, T. S., Richter, R. J., Schellenberg, G. D. and Furlong, C. E., Paraoxonase (PON1) phenotype is a better predictor of vascular disease than is PON1(192) or PON1(55) genotype, Arterioscler Thromb Vasc Biol, 2000, 20: 2441-2447.

[62] Mackness, B., Davies, G. K., Turkie, W., Lee, E., Roberts, D. H., Hill, E., Roberts, C., Durrington, P. N. and Mackness, M. I., Paraoxonase status in coronary heart disease: are activity and concentration more important than genotype?, Arterioscler Thromb Vasc Biol, 2001, 21: 1451-1457.

[63] Jarvik, G. P., Hatsukami, T. S., Carlson, C., Richter, R. J., Jampsa, R., Brophy, V. H., Margolin, S., Rieder, M., Nickerson, D., Schellenberg, G. D., Heagerty, P. J. and Furlong, C. E., Paraoxonase activity, but not haplotype utilizing the linkage disequilibrium structure, predicts vascular disease, Arterioscler Thromb Vasc Biol, 2003, 23: 1465-1471.

[64] Ferre, N., Camps, J., Fernandez-Ballart, J., Arija, V., Murphy, M. M., Ceruelo, S., Biarnes, E., Vilella, E., Tous, M. and Joven, J., Regulation of serum paraoxonase activity by genetic, nutritional, and lifestyle factors in the general population, Clin Chem, 2003, 49: 1491-1497.

[65] Mackness, M. I., Mackness, B., Durrington, P. N., Connelly, P. W. and Hegele, R. A., Paraoxonase: biochemistry, genetics and relationship to plasma lipoproteins, Curr Opin Lipidol, 1996, 7: 69-76.

[66] Adkins, S., Gan, K. N., Mody, M. and La Du, B. N., Molecular basis for the polymorphic forms of human serum paraoxonase/arylesterase: glutamine or arginine at position 191, for the respective A or B allozymes, Am J Hum Genet, 1993, 52: 598-608.

[67] Aviram, M., Billecke, S., Sorenson, R., Bisgaier, C., Newton, R., Rosenblat, M., Erogul, J., Hsu, C., Dunlop, C. and La Du, B., Paraoxonase active site required for protection against LDL oxidation involves its free sulfhydryl group and is different from that required for its arylesterase/paraoxonase activities: selective action of human paraoxonase allozymes Q and R, Arterioscler Thromb Vasc Biol, 1998, 18: 1617-1624. 
[68] Mackness, B., Durrington, P. N. and Mackness, M. I., Polymorphisms of paraoxonase genes and low-density lipoprotein lipid peroxidation, Lancet, 1999, 353: 468469.

[69] Ahmed, Z., Ravandi, A., Maguire, G. F., Emili, A., Draganov, D., La Du, B. N., Kuksis, A. and Connelly, P. W., Apolipoprotein A-I promotes the formation of phosphatidylcholine core aldehydes that are hydrolyzed by paraoxonase (PON-1) during high density lipoprotein oxidation with a peroxynitrite donor, J Biol Chem, 2001, 276: 24473-24481.

[70] Imai, Y., Morita, H., Kurihara, H., Sugiyama, T., Kato, N., Ebihara, A., Hamada, C., Kurihara, Y., Shindo, T., Oh-hashi, Y. and Yazaki, Y., Evidence for association between paraoxonase gene polymorphisms and atherosclerotic diseases, Atherosclerosis, 2000, 149: 435-442.

[71] Ko, Y. L., Ko, Y. S., Wang, S. M., Hsu, L. A., Chang, C. J., Chu, P. H., Cheng, N. J., Chen, W. J., Chiang, C. W. and Lee, Y. S., The Gln-Arg 191 polymorphism of the human paraoxonase gene is not associated with the risk of coronary artery disease among Chinese in Taiwan, Atherosclerosis, 1998, 141: 259-264.

[72] Ferre, N., Tous, M., Paul, A., Zamora, A., Vendrell, J. J., Bardaji, A., Camps, J., Richart, C. and Joven, J., Paraoxonase Gln-Arg(192) and Leu-Met(55) gene polymorphisms and enzyme activity in a population with a low rate of coronary heart disease, Clin Biochem, 2002, 35: 197-203.

[73] Zama, T., Murata, M., Matsubara, Y., Kawano, K., Aoki, N., Yoshino, H., Watanabe, G., Ishikawa, K. and Ikeda, Y., A 192Arg variant of the human paraoxonase (HUMPONA) gene polymorphism is associated with an increased risk for coronary artery disease in the Japanese, Arterioscler Thromb Vasc Biol, 1997, 17: 3565-3569.

[74] Odawara, M., Tachi, Y. and Yamashita, K., Paraoxonase polymorphism (Gln192-Arg) is associated with coronary heart disease in Japanese noninsulin-dependent diabetes mellitus, J Clin Endocrinol Metab, 1997, 82: 2257-2260.

[75] Sanghera, D. K., Saha, N., Aston, C. E. and Kamboh, M. I., Genetic polymorphism of paraoxonase and the risk of coronary heart disease, Arterioscler Thromb Vasc Biol, 1997, 17: 1067-1073.

[76] Serrato, M. and Marian, A. J., A variant of human paraoxonase/arylesterase (HUMPONA) gene is a risk factor for coronary artery disease, J Clin Invest, 1995, 96: 3005-3008.

[77] Ruiz, J., Blanche, H., James, R. W., Garin, M. C., Vaisse, C., Charpentier, G., Cohen, N., Morabia, A., Passa, P. and Froguel, P., Gln-Arg192 polymorphism of paraoxonase and coronary heart disease in type 2 diabetes, Lancet, 1995, 346: 869-872.

[78] Suehiro, T., Nakauchi, Y., Yamamoto, M., Arii, K., Itoh, H., Hamashige, N. and Hashimoto, K., Paraoxonase gene polymorphism in Japanese subjects with coronary heart disease, Int J Cardiol, 1996, 57: 69-73.

[79] Herrmann, S. M., Blanc, H., Poirier, O., Arveiler, D., Luc, G., Evans, A., Marques-Vidal, P., Bard, J. M. and Cambien, F., The Gln/Arg polymorphism of human paraoxonase (PON 192) is not related to myocardial infarction in the ECTIM Study, Atherosclerosis, 1996, 126: 299-303. 
[80] Antikainen, M., Murtomaki, S., Syvanne, M., Pahlman, R., Tahvanainen, E., Jauhiainen, M., Frick, M. H. and Ehnholm, C., The Gln-Arg191 polymorphism of the human paraoxonase gene (HUMPONA) is not associated with the risk of coronary artery disease in Finns, J Clin Invest, 1996, 98: 883-885.

[81] Rice, G. I., Ossei-Gerning, N., Stickland, M. H. and Grant, P. J., The paraoxonase GlnArg 192 polymorphism in subjects with ischaemic heart disease, Coron Artery Dis, 1997, 8: 677-682.

[82] Ombres, D., Pannitteri, G., Montali, A., Candeloro, A., Seccareccia, F., Campagna, F., Cantini, R., Campa, P. P., Ricci, G. and Arca, M., The gln-Arg192 polymorphism of human paraoxonase gene is not associated with coronary artery disease in italian patients, Arterioscler Thromb Vasc Biol, 1998, 18: 1611-1616.

[83] Garin, M. C., James, R. W., Dussoix, P., Blanche, H., Passa, P., Froguel, P. and Ruiz, J., Paraoxonase polymorphism Met-Leu54 is associated with modified serum concentrations of the enzyme. A possible link between the paraoxonase gene and increased risk of cardiovascular disease in diabetes, J Clin Invest, 1997, 99: 62-66.

[84] Sanghera, D. K., Saha, N. and Kamboh, M. I., The codon 55 polymorphism in the paraoxonase 1 gene is not associated with the risk of coronary heart disease in Asian Indians and Chinese, Atherosclerosis, 1998, 136: 217-223.

[85] Leviev, I., Negro, F. and James, R. W., Two alleles of the human paraoxonase gene produce different amounts of mRNA. An explanation for differences in serum concentrations of paraoxonase associated with the (Leu-Met54) polymorphism, Arterioscler Thromb Vasc Biol, 1997, 17: 2935-2939.

[86] Mackness, M. I., Walker, C. H. and Carlson, L. A., Low A-esterase activity in serum of patients with fish-eye disease, Clin Chem, 1987, 33: 587-588.

[87] Mackness, M. I., Peuchant, E., Dumon, M. F., Walker, C. H. and Clerc, M., Absence of "A"-esterase activity in the serum of a patient with Tangier disease, Clin Biochem, 1989, 22: 475-478.

[88] Ikeda, Y., Suehiro, T., Inoue, M., Nakauchi, Y., Morita, T., Arii, K., Ito, H., Kumon, Y. and Hashimoto, K., Serum paraoxonase activity and its relationship to diabetic complications in patients with non-insulin-dependent diabetes mellitus, Metabolism, 1998, 47: 598-602.

[89] Mackness, B., Durrington, P. N., Abuashia, B., Boulton, A. J. and Mackness, M. I., Low paraoxonase activity in type II diabetes mellitus complicated by retinopathy, Clin Sci (Lond), 2000, 98: 355-363.

[90] Mackness, M. I., Durrington, P. N., Ayub, A. and Mackness, B., Low serum paraoxonase: a risk factor for atherosclerotic disease?, Chem Biol Interact, 1999, 119-120: 389-397.

[91] James, R. W., Leviev, I. and Righetti, A., Smoking is associated with reduced serum paraoxonase activity and concentration in patients with coronary artery disease, Circulation, 2000, 101: 2252-2257.

[92] Senti, M., Tomas, M., Vila, J., Marrugat, J., Elosua, R., Sala, J. and Masia, R., Relationship of age-related myocardial infarction risk and Gln/Arg 192 variants of the human paraoxonase1 gene: the REGICOR study, Atherosclerosis, 2001, 156: 443449 . 
[93] Salonen, J. T., Malin, R., Tuomainen, T. P., Nyyssonen, K., Lakka, T. A. and Lehtimaki, T., Polymorphism in high density lipoprotein paraoxonase gene and risk of acute myocardial infarction in men: prospective nested case-control study, BMJ, 1999, 319: 487-489; discussion 490.

[94] Arca, M., Ombres, D., Montali, A., Campagna, F., Mangieri, E., Tanzilli, G., Campa, P. P., Ricci, G., Verna, R. and Pannitteri, G., PON1 L55M polymorphism is not a predictor of coronary atherosclerosis either alone or in combination with Q192R polymorphism in an Italian population, Eur J Clin Invest, 2002, 32: 9-15.

[95] Mackness, B., Mackness, M. I., Arrol, S., Turkie, W., Julier, K., Abuasha, B., Miller, J. E., Boulton, A. J. and Durrington, P. N., Serum paraoxonase (PON1) 55 and 192 polymorphism and paraoxonase activity and concentration in non-insulin dependent diabetes mellitus, Atherosclerosis, 1998, 139: 341-349.

[96] Patel, B. N., Mackness, M. I., Harty, D. W., Arrol, S., Boot-Handford, R. P. and Durrington, P. N., Serum esterase activities and hyperlipidaemia in the streptozotocin-diabetic rat, Biochim Biophys Acta, 1990, 1035: 113-116.

[97] Mackness, B., Durrington, P. N. and Mackness, M. I., Human serum paraoxonase, Gen Pharmacol, 1998, 31: 329-336.

[98] Rodrigo, L., Hernandez, A. F., Lopez-Caballero, J. J., Gil, F. and Pla, A., Immunohistochemical evidence for the expression and induction of paraoxonase in rat liver, kidney, lung and brain tissue. Implications for its physiological role, Chem Biol Interact, 2001, 137: 123-137.

[99] Leviev, I. and James, R. W., Promoter polymorphisms of human paraoxonase PON1 gene and serum paraoxonase activities and concentrations, Arterioscler Thromb Vasc Biol, 2000, 20: 516-521.

[100] Brophy, V. H., Hastings, M. D., Clendenning, J. B., Richter, R. J., Jarvik, G. P. and Furlong, C. E., Polymorphisms in the human paraoxonase (PON1) promoter, Pharmacogenetics, 2001, 11: 77-84.

[101] Suehiro, T., Nakamura, T., Inoue, M., Shiinoki, T., Ikeda, Y., Kumon, Y., Shindo, M., Tanaka, H. and Hashimoto, K., A polymorphism upstream from the human paraoxonase (PON1) gene and its association with PON1 expression, Atherosclerosis, 2000, 150: 295-298.

[102] Deakin, S., Leviev, I., Brulhart-Meynet, M. C. and James, R. W., Paraoxonase-1 promoter haplotypes and serum paraoxonase: a predominant role for polymorphic position - 107, implicating the Sp1 transcription factor, Biochem J, 2003, 372: 643649.

[103] Brophy, V. H., Jampsa, R. L., Clendenning, J. B., McKinstry, L. A., Jarvik, G. P. and Furlong, C. E., Effects of 5' regulatory-region polymorphisms on paraoxonase-gene (PON1) expression, Am J Hum Genet, 2001, 68: 1428-1436.

[104] Gouedard, C., Koum-Besson, N., Barouki, R. and Morel, Y., Opposite regulation of the human paraoxonase-1 gene PON-1 by fenofibrate and statins, Mol Pharmacol, 2003, 63: 945-956.

[105] James, R. W., Leviev, I., Ruiz, J., Passa, P., Froguel, P. and Garin, M. C., Promoter polymorphism $\mathrm{T}(-107) \mathrm{C}$ of the paraoxonase PON1 gene is a risk factor for coronary heart disease in type 2 diabetic patients, Diabetes, 2000, 49: 1390-1393. 
[106] Cambien, F., Genes in population. In: Malcolm,S.Goodship, J. (eds), Genotype to Phenotype. Academic Press, Guildford, UK, pp 31-53, 2001.

[107] Hegele, R. A., Brunt, J. H. and Connelly, P. W., A polymorphism of the paraoxonase gene associated with variation in plasma lipoproteins in a genetic isolate, Arterioscler Thromb Vasc Biol, 1995, 15: 89-95.

[108] Leus, F. R., Zwart, M., Kastelein, J. J. and Voorbij, H. A., PON2 gene variants are associated with clinical manifestations of cardiovascular disease in familial hypercholesterolemia patients, Atherosclerosis, 2001, 154: 641-649.

[109] Van Lenten, B. J., Hama, S. Y., de Beer, F. C., Stafforini, D. M., McIntyre, T. M., Prescott, S. M., La Du, B. N., Fogelman, A. M. and Navab, M., Anti-inflammatory HDL becomes pro-inflammatory during the acute phase response. Loss of protective effect of HDL against LDL oxidation in aortic wall cell cocultures, J Clin Invest, 1995, 96: 2758-2767.

[110] Gonzalvo, M. C., Gil, F., Hernandez, A. F., Villanueva, E. and Pla, A., Inhibition of paraoxonase activity in human liver microsomes by exposure to EDTA, metals and mercurials, Chem Biol Interact, 1997, 105: 169-179.

[111] Debord, J., Bollinger, J. C., Merle, L. and Dantoine, T., Inhibition of human serum arylesterase by metal chlorides, J Inorg Biochem, 2003, 94: 1-4.

[112] Furlong, C. E., Cole, T. B., Jarvik, G. P. and Costa, L. G., Pharmacogenomic considerations of the paraoxonase polymorphisms, Pharmacogenomics, 2002, 3: 341-348.

[113] Kaliste-Korhonen, E., Torronen, R., Ylitalo, P. and Hanninen, O., Inhibition of cholinesterases by DRP and induction of organophosphate-detoxicating enzymes in rats, Gen Pharmacol, 1990, 21: 527-533.

[114] Costa, L. G. and Furlong, C. E., Paraoxonase (PON1) in Health and Disease: Basic and Clinical Aspects. Kluwer Academic Publishers, Boston, USA., 2002.

[115] Kaliste-Korhonen, E., Tuovinen, K. and Hanninen, O., Effect of phenobarbital and betanaphthoflavone on activities of different rat esterases after paraoxon exposure, Gen Pharmacol, 1998, 31: 307-312.

[116] Vitarius, J. A., O'Shaughnessy, J. A. and Sultatos, L. G., The effects of phenobarbital pretreatment on the metabolism and toxicity of paraoxon in the mouse, Pharmacol Toxicol, 1995, 77: 16-22.

[117] Playfer, J. R., Powell, C. and Evans, D. A., Plasma paroxonase activity in old age, Age Ageing, 1977, 6: 89-95.

[118] Zech, R. and Zurcher, K., Organophosphate splitting serum enzymes in different mammals, Comp Biochem Physiol B, 1974, 48: 427-433.

[119] Feingold, K. R., Memon, R. A., Moser, A. H. and Grunfeld, C., Paraoxonase activity in the serum and hepatic mRNA levels decrease during the acute phase response, Atherosclerosis, 1998, 139: 307-315.

[120] Pervaiz, S., Resveratrol: from grapevines to mammalian biology, FASEB J, 2003, 17: 1975-1985.

[121] Weitman, S. D., Vodicnik, M. J. and Lech, J. J., Influence of pregnancy on parathion toxicity and disposition, Toxicol Appl Pharmacol, 1983, 71: 215-224. 
[122] Nishio, E. and Watanabe, Y., Cigarette smoke extract inhibits plasma paraoxonase activity by modification of the enzyme's free thiols, Biochem Biophys Res Commun, 1997, 236: 289-293.

[123] Aviram, M. and Fuhrman, B., Wine flavonoids protect against LDL oxidation and atherosclerosis, Ann N Y Acad Sci, 2002, 957: 146-161.

[124] Durrington, P. N., Mackness, B. and Mackness, M. I., The hunt for nutritional and pharmacological modulators of paraoxonase, Arterioscler Thromb Vasc Biol, 2002, 22: $1248-1250$.

[125] Fuhrman, B. and Aviram, M., Preservation of paraoxonase activity by wine flavonoids: possible role in protection of LDL from lipid peroxidation, Ann N Y Acad Sci, 2002, 957: 321-324.

[126] Debord, J., Dantoine, T., Bollinger, J. C., Abraham, M. H., Verneuil, B. and Merle, L., Inhibition of arylesterase by aliphatic alcohols, Chem Biol Interact, 1998, 113: 105115.

[127] van der Gaag, M. S., van Tol, A., Scheek, L. M., James, R. W., Urgert, R., Schaafsma, G. and Hendriks, H. F., Daily moderate alcohol consumption increases serum paraoxonase activity; a diet-controlled, randomised intervention study in middleaged men, Atherosclerosis, 1999, 147: 405-410.

[128] Hayek, T., Fuhrman, B., Vaya, J., Rosenblat, M., Belinky, P., Coleman, R., Elis, A. and Aviram, M., Reduced progression of atherosclerosis in apolipoprotein E-deficient mice following consumption of red wine, or its polyphenols quercetin or catechin, is associated with reduced susceptibility of LDL to oxidation and aggregation, Arterioscler Thromb Vasc Biol, 1997, 17: 2744-2752.

[129] Aviram, M., Dornfeld, L., Rosenblat, M., Volkova, N., Kaplan, M., Coleman, R., Hayek, T., Presser, D. and Fuhrman, B., Pomegranate juice consumption reduces oxidative stress, atherogenic modifications to LDL, and platelet aggregation: studies in humans and in atherosclerotic apolipoprotein E-deficient mice, Am J Clin Nutr, 2000, 71: 1062-1076.

[130] Kaplan, M., Hayek, T., Raz, A., Coleman, R., Dornfeld, L., Vaya, J. and Aviram, M., Pomegranate juice supplementation to atherosclerotic mice reduces macrophage lipid peroxidation, cellular cholesterol accumulation and development of atherosclerosis, J Nutr, 2001, 131: 2082-2089.

[131] Forte, T. M., Subbanagounder, G., Berliner, J. A., Blanche, P. J., Clermont, A. O., Jia, Z., Oda, M. N., Krauss, R. M. and Bielicki, J. K., Altered activities of anti-atherogenic enzymes LCAT, paraoxonase, and platelet-activating factor acetylhydrolase in atherosclerosis-susceptible mice, J Lipid Res, 2002, 43: 477-485.

[132] Hedrick, C. C., Hassan, K., Hough, G. P., Yoo, J. H., Simzar, S., Quinto, C. R., Kim, S. M., Dooley, A., Langi, S., Hama, S. Y., Navab, M., Witztum, J. L. and Fogelman, A. M., Short-term feeding of atherogenic diet to mice results in reduction of HDL and paraoxonase that may be mediated by an immune mechanism, Arterioscler Thromb Vasc Biol, 2000, 20: 1946-1952.

[133] Shih, D. M., Gu, L., Hama, S., Xia, Y. R., Navab, M., Fogelman, A. M. and Lusis, A. J., Genetic-dietary regulation of serum paraoxonase expression and its role in atherogenesis in a mouse model, J Clin Invest, 1996, 97: 1630-1639. 
[134] de Roos, N. M., Schouten, E. G., Scheek, L. M., van Tol, A. and Katan, M. B., Replacement of dietary saturated fat with trans fat reduces serum paraoxonase activity in healthy men and women, Metabolism, 2002, 51: 1534-1537.

[135] Wallace, A. J., Sutherland, W. H., Mann, J. I. and Williams, S. M., The effect of meals rich in thermally stressed olive and safflower oils on postprandial serum paraoxonase activity in patients with diabetes, Eur J Clin Nutr, 2001, 55: 951-958.

[136] Tomas, M., Senti, M., Elosua, R., Vila, J., Sala, J., Masia, R. and Marrugat, J., Interaction between the Gln-Arg 192 variants of the paraoxonase gene and oleic acid intake as a determinant of high-density lipoprotein cholesterol and paraoxonase activity, Eur J Pharmacol, 2001, 432: 121-128.

[137] Sutherland, W. H., Walker, R. J., de Jong, S. A., van Rij, A. M., Phillips, V. and Walker, H. L., Reduced postprandial serum paraoxonase activity after a meal rich in used cooking fat, Arterioscler Thromb Vasc Biol, 1999, 19: 1340-1347.

[138] Aviram, M., Rosenblat, M., Billecke, S., Erogul, J., Sorenson, R., Bisgaier, C. L., Newton, R. S. and La Du, B., Human serum paraoxonase (PON 1) is inactivated by oxidized low density lipoprotein and preserved by antioxidants, Free Radic Biol Med, 1999, 26: 892-904. 


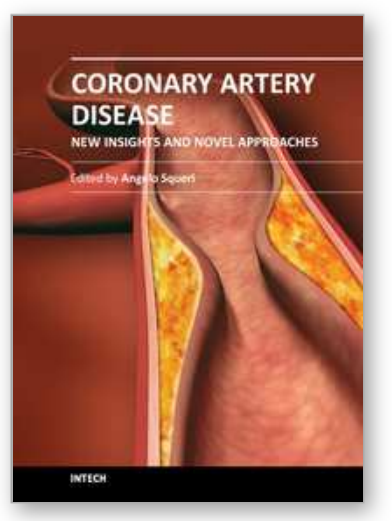

\author{
Coronary Artery Disease - New Insights and Novel Approaches \\ Edited by Dr. Angelo Squeri
}

ISBN 978-953-51-0344-8

Hard cover, 260 pages

Publisher InTech

Published online 16, March, 2012

Published in print edition March, 2012

Coronary Artery disease is one of the leading causes of death in industrialized countries and is responsible for one out of every six deaths in the United States. Remarkably, coronary artery disease is also largely preventable. The biggest challenge in the next years is to reduce the incidence of coronary artery disease worldwide. A complete knowledge of the mechanisms responsible for the development of ischaemic heart disease is an essential prerequisite to a better management of this pathology improving prevention and therapy. This book has been written with the intention of providing new concepts about coronary artery disease pathogenesis that may link various aspects of the disease, going beyond the traditional risk factors.

\title{
How to reference
}

In order to correctly reference this scholarly work, feel free to copy and paste the following:

Nidhi Gupta, Kiran Dip Gill and Surjit Singh (2012). Paraoxonase 1 (PON1) Activity, Polymorphisms and Coronary Artery Disease, Coronary Artery Disease - New Insights and Novel Approaches, Dr. Angelo Squeri (Ed.), ISBN: 978-953-51-0344-8, InTech, Available from: http://www.intechopen.com/books/coronary-arterydisease-new-insights-and-novel-approaches/paraoxonase-1-pon1-activity-polymorphisms-and-coronaryartery-disease

\section{INTECH}

open science | open minds

\section{InTech Europe}

University Campus STeP Ri

Slavka Krautzeka 83/A

51000 Rijeka, Croatia

Phone: +385 (51) 770447

Fax: +385 (51) 686166

www.intechopen.com

\author{
InTech China \\ Unit 405, Office Block, Hotel Equatorial Shanghai \\ No.65, Yan An Road (West), Shanghai, 200040, China \\ 中国上海市延安西路65号上海国际贵都大饭店办公楼405单元 \\ Phone: +86-21-62489820 \\ Fax: +86-21-62489821
}


(C) 2012 The Author(s). Licensee IntechOpen. This is an open access article distributed under the terms of the Creative Commons Attribution 3.0 License, which permits unrestricted use, distribution, and reproduction in any medium, provided the original work is properly cited. 